\title{
Institutions of Change: Kathak dance from Courts to Classrooms
}

\author{
Suman Bhagchandani \\ Ph.D. scholar of English at Jamia Milia University, Delhi. Orcid: oooo-ooo1-9525-2697. \\ Email: sumanbhagchandani@gmail.com
}

\begin{abstract}
:
This paper is a study of the progress of Kathak from the erstwhile courtesan culture to the contemporary classroom, structured practice. It aims to highlight the works of contributors like Nirmala Joshi and Sumitra Charat Ram as the pioneers of institutional Kathak that completely divorced its cultural past in the Mughal courts. Amidst all this cleansisng of Kathak history, Madame Menaka, one of the first female Kathak dancers to perform on the proscenium stage and to legitimise her presence by her association with insitutions of Kathak stands out. Madame Menaka truly deserves more attention in dance history and this paper aims to celebrate her life and works in Kathak. These artists and art entrepreneurs have never come together on the same platform for their contributions in the field of art and culture as they do in this paper. Their works lie scattered in biographies and articles that perform a discrete study on each of them. This paper is therefore an attempt to draw a linear development of Kathak through the works of female art contributors.
\end{abstract}

Keywords: Kathak, Madame Menaka, Mughal courts, courtesan culture

\section{Introduction}

Kathak recognised by the Sangeet Natak Akademy as one of the eight classical dances of India is known for its precision in foot-work, fast pirrouttes, fine expressions, and its story-telling tradtion. While the former kinesthtetic skills in dance is a recent development, it's the folkloric tradition of reciting stories that we closely associate with the dance history of Kathak. Sunil Kothari in his reading of Kathak draws a connection between references to the Kathaka caste in mythological epics like the Mahabharata and the Ramayana and their religious Hindu roots (Kothari 1989, 1). A later reference in this paper is made by me to this rather political association of Kathak with a specific religious influence when I mention the contribution of Nirmala Joshi and Sumitra Charat Ram in the propogation of religious Kathak. On the other hand, critics like Kapila Vatsyayan and Pallabi Chakravorty have a more secular outlook towards Kathak, each of whom spread it across the northern belt of India, placing Kathak under the influence of Sufi tradition (Vatsyayan 1982, 89) and the various castes of Bengal, Bihar and Uttar Pradesh (Chakravorty 2008, 26) that allows a diversity of opinion to exist regarding its historical development.

Most critics however agree on the significant contribution of Mughal cultural influences on Kathak that relocated Kathak from the temples to the aristocratic courts bringing with it mutations in dance style, choice of costume, ensemble of musicians, and range of themes in performance. Abul Fazl, in A'in-i-Akbari (1593, trans. 1927) has curated these developments which have been a rich source for critics like Kapila Vatsyayan, Bonie C. Wade, and Margaret E. Fuller in

(c) AesthetixMS 2018. This Open Access article is published under a Creative Commons Attribution Non-Commercial 4.0 International License (http://creativecommons.org/licenses/by-nc/4.o/), which permits non-commercial re-use, distribution, and reproduction in any medium, provided the original work is properly cited. For citation use the DOI. For commercial re-use, please contact editor@chitrolekha.com 
reading Kathak in the Mughal era. It is from the wroks of these critics that we can see the advancement of Kathak from a folkloric and religious art form to a more syncretic practice. Also one of the most eminent changes that took place in the Mughal courts of Northern India were the presence of female Kathak dancers. Earlier references to Kathak in the pre-Mughal era have ignored the presence of female Kathak dancers, emphasizing on the contribution of men as its main practioners. This shift in power is most critically analyzed in Veena Oldenburg's work 'Life as Resistance: The Case of Courtesans of Lucknow' that acknowledges the dominant presence of female Kathak dancers in the Mughal courts. These dancers are appreciated not only for their knowledge of the dance form but also for their close association with the lifestyle of the nobility. As the cultural members of the royal household, the female dancers were hired for the task of raising and educating youg boys in matters of etiquette, appreciation of art and culture, and the study of Urdu literature (Oldenburg 1984, 124-144). This matrileneal society formed by the Kathak dancers in the Mughal courts has been of keen interest to scholars and ctitics alike, especially those who study the marginalisation of female Kathak gurus in the later stages of its development.

The third stage of development is the influential changes brought in by the British colonisation of art and culture in India. Though the details of the tawa'if culture, as courtesan dance came to be known in the Mughal courts in its later stages, is beyond the scope of this paper, it is important to know about the homogenization of different ranks of courtesans as common prostitutes. Both Oldenburg and Walker give a detailed account of the intermixing of learned tawa'ifs with dancers meant for pubic entertainment, by British colonials, who collectively labelled them as nautch (natuch: naach or dance) dancers.

The exotic allure of the nautch, however, faded as the nineteenth century progressed...One of the first priorities of Raj, formed in 1858 by the British Act of Parliament, was to ensure that the population was under control that the violence and rebellion of the 1857 uprising could never happen again....the initiation of controlling methods like health inspections, identity tickets, and registration for 'public women' contributed further in lowering the status of professional women performers. (Walker 2014, 93-94)

This problematic uniform view of courtesans as public performers was first brought under attack in the Anti-Nautch Movement in Madras in the year 1892 that aimed at sanitizing the country of its socio-cultural diseases.

A similar intitative took place in the city of Calcutta that expanded its socio-cultural boundaries to accommodate new thinkers and reformers across the nation. Enlightenment of the masses through the medium of art and culture implied an integral part of their agenda. Reformation was thus sort not by rejection of the past, but by exploiting the local and national history; nostalgia was stirred across the nation to join its citizens in a shared historical past. Cultural hegemony of the past was acclaimed and Calcutta which once celebrated nautch performances in religious festivities turned its back upon it during this period. It was with the efforts of socialists like Keshub Sen to sanitize the city that the nautch (naach: dance) culture was relegated to the margins and widely associated with trafficking of women. On the other hand an urgent need to fill this cultural void was felt by art propagandists and Orientalists, alike. Nationalists in the interest of fine and performing arts thus harked upon the ancient associations to recreate its history. As Tapati Guha-Thakurta points out,

The hiatus between the past and the present, it was felt, could only be bridged by reinculcating "superior" forms of art practice and new "authentic" forms of knowledge in Indian art. The past, as a symbol of the nation's autonomous history and civilizational lineage, had to prepare the way for 
a present where tradition and modernized knowledge would together frame a new self. (Thakurta $1983,140)$

The above quoted essay proceeds to trace the revival of sculpture and architecture and its propagation through print media, in Bengal-an integral part of the nationalist endeavourswhich resolved back to its ethnographic roots. Guha-Thakurta traverses through the works of Shyamcharan Srimani (Suksa Shilper Utpatti o Aryajatir Shilpa-chaturi, trans. The Rise of the Fine Arts and the Artistic Skills of the Aryans, 1874) and Abanindranath Tagore (Bharat Shilpa, 1909), both of whom bridged the gap between ancient religious inclinations with the present cultural atmosphere (Thakurta 1983, 141). The common ground shared by them in the linear historical development of art generated a feeling of nationhood and belongingness amongst its readers. It was during this period of patriotic nationalism promoted by fine art and architecture that dance and music was revised in the cultural front. Through the rediscovery of the Natyashastra by Edward Hall in 1865, and its subsequent printing in 1874 and 1884, dance restoration was launched as a part of the orientalist project.

In 1899, Leila Roy (later Sokhey), born to an English mother and a Bengali father, was soon to join the league of dance revivalism. At an early age, she was introduced to the dance ballets of Anna Pavlova and had developed interest for it. However, it was only after Leila's marriage to Dr. Sahib Singh Sokhey that she received an opportunity to learn classical dance. This paper focuses on the rebirth of Kathak with the efforts of Leila Sokhey, popular with the pseudonym Madame Menaka; her brief but significant contribution towards classicizing nautch as Kathak; and her endeavours at capitalising the oriental culture on an international stage as a part of the larger nationalist project. In order to establish this argument, I will begin by looking at Abanindranath Tagore's exercising of national nostalgia to organise art in an ethnographic frame and the manner in which Madame Menaka employs the same to legitimise dance as a proscenium performance.

The second section of the paper proposes to explore Delhi as the new cultural capital in the early twentieth century. The mushrooming of private institutes-founded by the rising middle-class-as the centre for cultural propagation. In this section I will trace the reformation in Kathak by Nirmala Joshi and Maya Rao through the establishment of cultural institutions in Delhi. The paper will also highlight print capitalism as the means of formalizing classical dance forms to expand its readership/viewership. This argument will lead us to Benedict Anderson's discourse on imagined communities to look at the manner in which print and visual media advances fraternity amongst its consumers. In this section I will draw parrallels between the rise of print culture in India with linguistic hierarchy established through Hindi nationalism. It is through this prism of language that I will pass Kathak to look at the changes in pedagogy that have emerged post-nationalism. To further my argument I will briefly look at national radio and television broadcasting and the role they performed in catalysing the process of cultural development.

I shall therefore attempt to bring out through this chapter the life and works of Madame Menaka in the light of the rebirth of Kathak and its subsequent nationalization postIndependence. 
44 | The Chitrolekha Journal on Art and Design, Vol. 2, No. 1, 2018

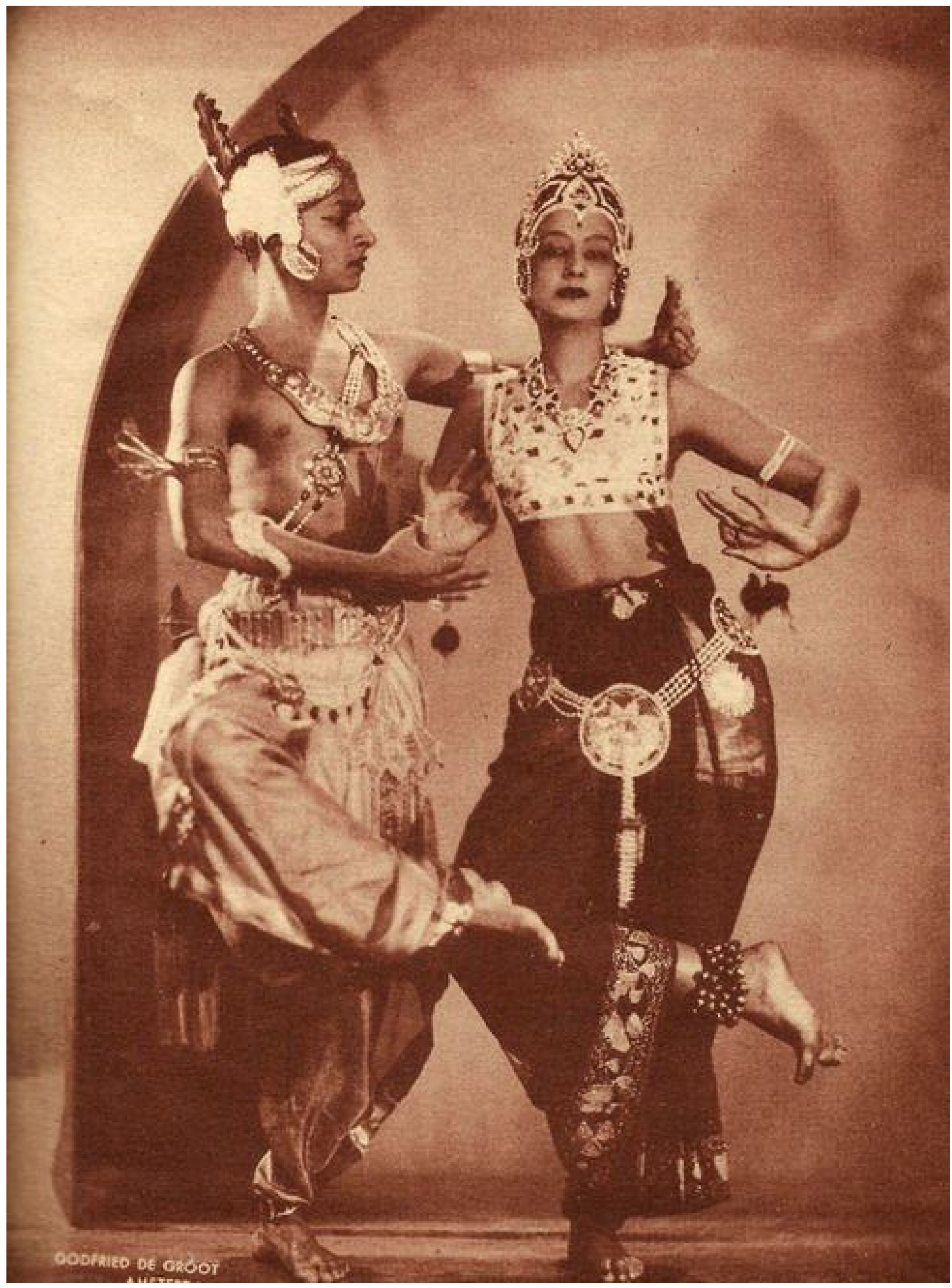

Fig. 1. Madame Menaka and Ramnarayan in Deva Vijaya Nritya 


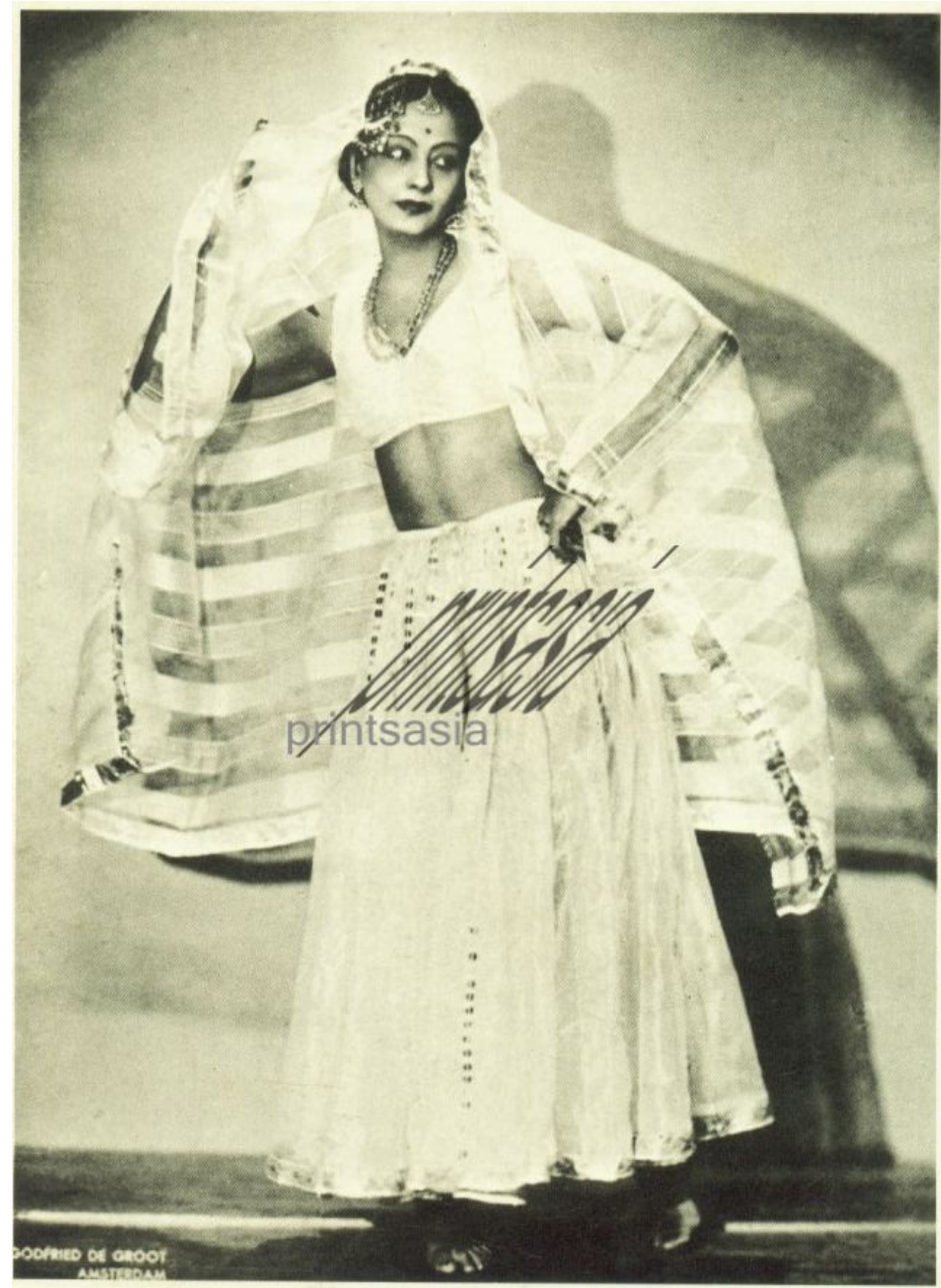

Fig. 2 Madame Menaka

\section{Life and Works of Madame Menaka}

Leila Sokhey's training in Kathak began in Bombay, under the patronage of Pandit Sitaram Prasad of the Lucknow gharana. Financed by Dr. Sokhey, Pandit Sitaram travelled to Bombay to teach Leila the art of Kathak. This was the first step towards reversing the traditional relationship between the guru and the shishya whereby the guru stayed with the shishya, than otherwise. Panditji's stay at Leila's residence allowed her to acknowledge the art form closely and prepared 
her for the proscenium stage. Adopting Madame Menaka as the stage-name, Leila initiated the process of revising Kathak in the 1920s. Menaka's performances were a deliberate effort at erasing the traces of Mughal associations in Kathak, thereby replacing the narratives and style of performance by religious Hindu accounts ${ }^{i}$. Ancient Hindu texts were carefully selected to provide the script for dance dramas and a spiritual element in dance was performed on stage in order to engage the audience in a divine experience ${ }^{\text {ii. }}$ The element of spirituality in dance was not a novel technique introduced by Menaka. Udaya Shankar had already exploited the possibility of fusing religious traditions with performance on stage. However, Shankar's dance did not follow any conventional art form and gradually receded into the background as classical dances with similar themes took its place.

Few of the instances of the mutations in the style of performance and choice of subject is evident in the widely popoular performances by Madame Menaka in the following years. In 1934, Madame Menaka, with the guidance of Pandit Sundar Prasad, performed in a dance ballet called Krishna-Leela for Bombay Opera House. The costumes were selected and designed by Menaka, inspired by Udaya Shankar and Anna Pavalova, in an imitation of the Rajput paintings. The dance was scripted around the Krishna-Radha folklore, evoking the rasa bhava through the performance. Menaka's relationship with Pandit Sundar Prasad was short-lived and he was soon replaced by the Kathak maestro, Pandit Acchan Maharaj. In 1935, a dance-drama composed in three scenes called the Deva Vijaya Nritya followed league. In this Menaka played the role of Mohini, the female incarnation of Lord Vishnu, often considered synonymous with a temptress. Deva Vijaya Nritya, as the name suggests, recites the tale of the Hindu God's victory over demons to possess Amrita or the elixir of life. The last section of the drama revolves around Mohini's temptation of Shiva and Shiva's triumph over his passions (Joshi 1982, 14).

The most significant aspect which evolves from these performances is the retelling of the Hindu mythological tales through the medium of Kathak. The ethnographic detail within which the dance was framed was significant in the context of its restoration as a part of the larger nationalistic project of cultural development. To support my argument, I would like to refer to Partha Chatterjee's reading of the spiritual domain as the agency for the manifestation of cultural nationalism. In The Nation and its Fragments, Chatterjee outlines the criticism of traditional socio-cultural practices of the East during the colonial period and the hierarchy of values this implied. The East organised its cultural practice around superior, spiritual beliefs and the West was bracketed as 'the material domain' that 'lies outside us-a mere external that influences us, conditions us, and forces us to adjust to it. Ultimately, it is unimportant. The spiritual, which lies within, is our true self; it is that which is genuinely essential.' So long as India foregrounded the spiritual elements in cultural practices, it could adapt itself to the modern influences of the West, 'without losing its identity.' (Chatterjee 1993, 120)

In order to foreground a spiritually oriented tradition in dance practices, hymns like Ganesh Vandana (Invocation to Lord Ganesha) and Saraswati Vandana (Invocation to Godsess Saraswati) preceded the main narrative of Kathak. The divine invocation at the beginning of the performance therefore legitimised the presence of a female dancer on the proscenium stage, subjected to the public gaze. At the same time, employment of spiritual elements in performance also confered the female dancer with the responsibility of representing the nation, imagined as possessing 'qualities of self-sacrifice, benevolence, devotion, religiosity, and so on.' (Chatterjee 1993, 131) The equation derived between the nation and the female woman thus revised the hegemonic practices in society in a paradoxical manner by emancipating women to occupy the public sphere through performance, but also confining them within the historical (spiritual) 
narrative of the nation. Urmimala Sarkar in her paper entitled 'Traversing Traditions: Women in the Public Sphere' takes the example of State organised festivals like Khajuraho and Konark Dance Festival that provides the space for the execution of 'tradition, that implies the disciplined bodies' as well as the 'disciplinable bodies' of the performer. The performing body of the dancer, in these festivals, is placed against the carved images of goddesses in a dance posture. The dancer on the stage thus emerges before the audience as a living embodiment of the space around it. At the same time, the continuous presence of the architectural carving of the dancing bodies on stone mobilises patriarchal and hegemonic power of the earlier rulers in a sense of timeless sovereignty and legitimises the female dancer in a public space. The evaluation of the performer rests on the manner in which she adopts the status of a standard bearer of tradition, as well as delivers herself as an example for the generations to come (Sarkar 2015).

The East/West dichotomy was intensified when the kinesthetics of dance were codified into complex combinations of hand gestures and footwork during its classicization. Unlike Bharatnatyam which relied on literature and strictly followed the mudras assigned to the dance form (in the Natyashastra), Kathak continued to enjoy the art of improvisation for a much longer period. In fact, it was the licence to modify dance which attracted Madame Menaka to learn the art of Kathak. The lack of codification in Kathak is apparent in her early performances with Udaya Shankar, demonstrating the emphasis on spectatorship rather than sophistication ${ }^{\text {iii }}$. Gradually, the distinction between Shankar's 'modern ballet' and classical Kathak was established by orchestrating skill through complex footwork and hand gestures by Menaka. In an article written in 1933 issue of Sound and Shadow, Madame Menaka historicizes these gestures in Kathak as the dance of Goddess Parvati and Kathakali, with the dance of Lord Shiva (qtd. in Joshi 54). The classification of various dances in ancient Hindu mythology not only gave a linear historical development to the art form, but also institutionalised the technique evolved by her. Excellence in performance became the new mantra for its popularisation amongst the 'pundits' of dance, and for those "who are not well versed in the exact knowledge of the technique should, because of this perfection, be enthralled by the beauty of the dance, which could not possibly be beautiful if the technique was not perfect."' (qtd. in Joshi 1982, 56)

As mentioned earlier, cryptic dance movements and culturally codified language made India's national culture appear superior and spectacular to the Western audience. However, that which captivated the West was received with scepticism in the East. Menaka's attempts at systemising the pedagogy of Kathak was not only attacked along gender lines but also seen as a Westernised influence (Joshi 1982, 31). Those who belonged to the court culture claimed to be Kathak's true patrons and anything outside the 'tradition' was deemed modern and hence nonclassical. 'After the classical dances received a new lease of life in the wake of nationalism and revival, the old masters were once again discovered with a view to establish them in the society as the repositories of art and who in turn can pass on the precious knowledge following the gurushishya parampara through institutions.' (Kothari 1989, 179) Male patrons of art who belonged to the traditional gharanas of Kathak were institutionalised in the new cultural capital of IndiaDelhi. Patriarchal domination in cultural practices therefore once again marginalised the autonomous female dancer to a subservient status of baiji.

In the pedagogy of cultural practices, the conflict between modern and traditional methodology was documented by national musicologists, especially by Bhatkhande and Paluskar. Janaki Bhakle in Two Men and Music traces the ideological differences between Bhatkhande's secular nationalism and Paluskar's ethnographical nationalism, in the renaissance of Hindustani music. The book traces the syncretic amalgam of different schools of thought in music during its 
instutionalisation. However, unlike music, Kathak's cultural topography was scattered across ethnographical, geographical and gender lines and a similar syncretic model was not practical in dance. Claimants for different styles of Kathak emerged from various places in North India, drawing links from their ancestors and constructing it around religious folklore. The two main gharanas that emerged during this period were the Lucknow gharana of the Mughal courts which had its origins in Krishnaleela (performed by Thakur Prasadji), hence the name Natwari Nritya ${ }^{i v}$; the other being, the Jaipur gharana which was performed by Giridhari in the courts and had its origins in the Shiva tandava. As a result, the Lucknow gharana highlights expressions and sensuousness as its main elements (feminine) and the Jaipur gharana, its footwork (masculine) ${ }^{\mathrm{v}}$.

Orientation of Kathak around geographical and cultural zones dominated by male patronage marginalised the presence of female Kathak dancers, outside the tradition (gharana). Delhi became the giant magnet of cultural capitalism that attracted male gharanedar gurus, sheltering the interests of both Jaipur and Lucknow gharnas of Kathak. At this time, Menaka's attempt at establishing a counter-cultural zone at Bombay through Nrityalam attracted a relatively small audience. As an autonomous institute administered by a female, Nrityalam's progress was also impeded by the overpowering influence of the Bollywood industry-an alternate zone of popular culture in the years to come. 'Bombay held out attractions to the musicians in the troupe, chiefly in the form of engagements intruding upon the routine. Though professionals received a regular pay, money was hard to resist, and the cost to troupe discipline slowly mounted.' (Joshi 1982, 32) Though she shifted the school to Khandala in 1941 and back to Bombay in 1944, the decline was apparent in the falling number of students and her failing health.
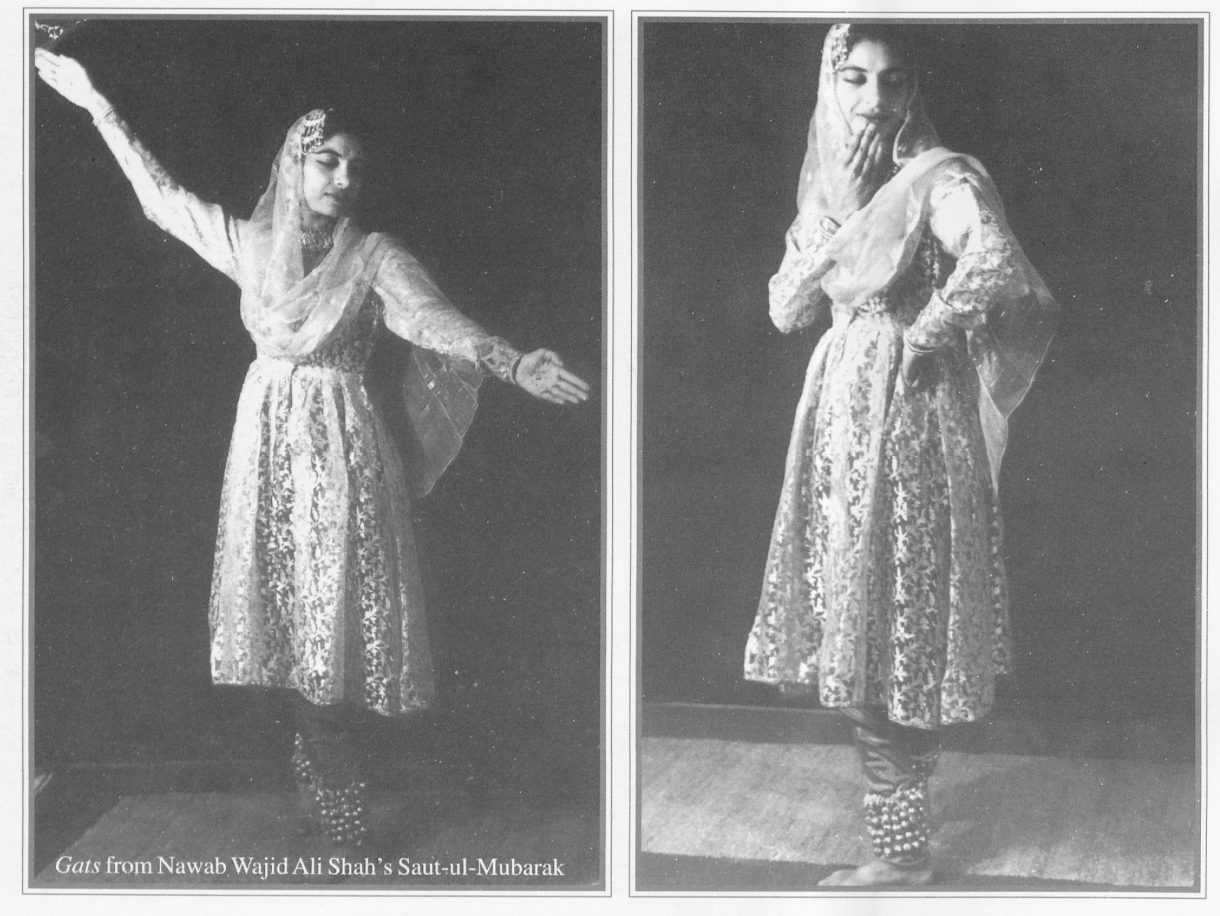

Fig. 3. A dancer performing in Mughal style of Kathak (Khokar 34)

(Photograph Courtesy: Sangeet Natak Akademy, Delhi)

In 1947, Madame Menaka's demise brought an end to Nrityalam too. As a consequence, Madame Menaka's name as the pioneer of classical Kathak receded into the background. Though 
Menaka's name has been acknowledge by dance scholars in their paper presentations (1958 Sangeet Natak Akademy audio archives), it was not until 1989 with the publication of Damyanti Joshi's biography on Madame Menaka, that her contribution in the field of Kathak was recognized. One of the reasons for the complete marginalisation of Madame Menaka was, as mentioned earlier, the rise of ancestral patronage of Kathak gurus. This ancient pedagogical practice was revived by the entrepreneurs of culture and anything outside the 'tradition' was seen as a threat to the national heritage. Around this time, the classicization of Kathak in North India was organised as a counter-cultural forum by the new capitalist class, which in its later stages developed into a Hindu nationalist movement.

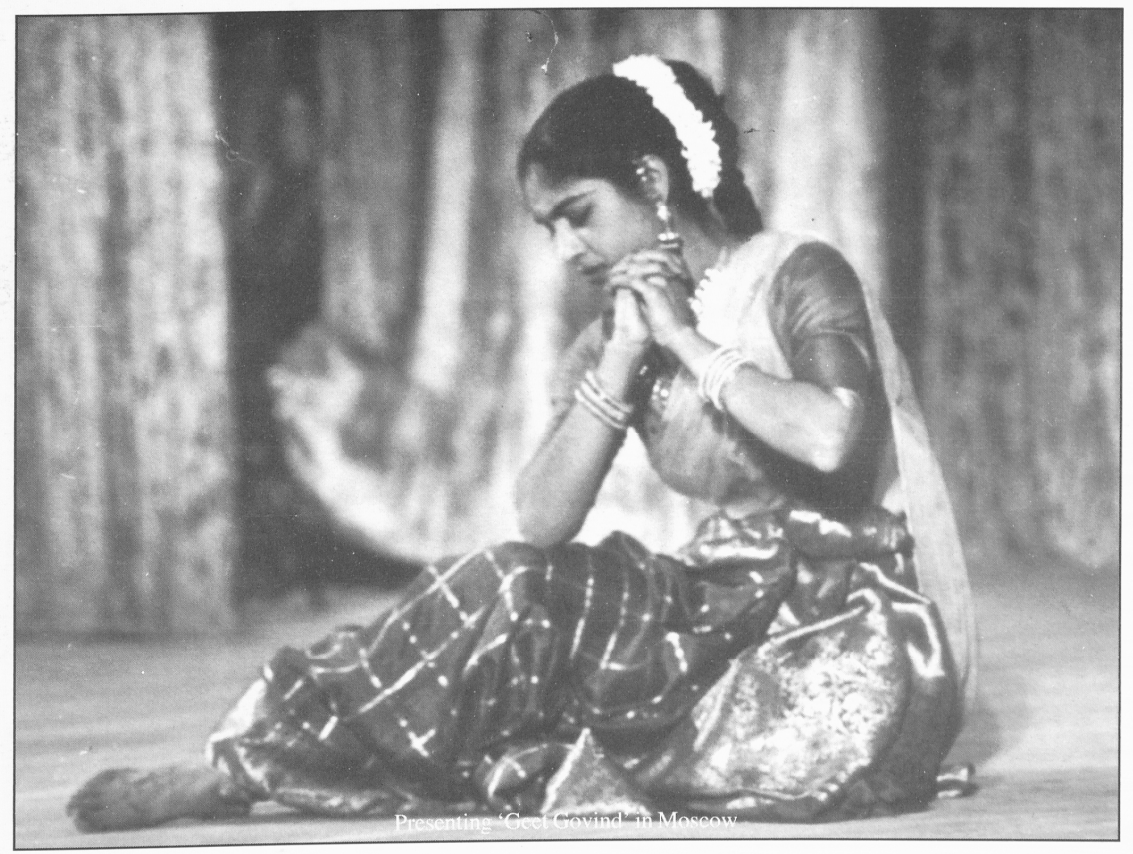

Fig. 4. A dancer performing in Moscow on 'Geet Govind' (Khokar 35)

(Photograph Courtesy: Sangeet Natak Akademy, Delhi)

\section{The institutional making of Kathak}

In 1936, Nirmala Joshi, an art activist, laid the foundation of the Delhi School of Hindustani Music and Dance. With a vision to encourage youth participation in performing arts, Joshi set out to invite Achchan Maharaj of the Lucknow gharana of Kathak to propagate the classical dance form on a national scale. This was the beginning of a non-hereditary and syncretic restoration of institutional Kathak in pre-Independence India. In the years to follow, Delhi School of Hindustani Music and Dance was renamed as Sangeet Bharati, which still functions at Mandi House, Delhi. Though much has not been documented on Joshi's early efforts, her active engagement with the national school of art the Bhartiya Kala Kendra or Kathak Kendra (later) is evident in its rapid development. As an entrepreneur and enthusiast of art, Joshi attracted many friends like Kaplia Malik (later Vatsyayan) and Sumitra Charat Ram, both of whom shared her interests. Kapila was the first student of Achchan Maharaj in Joshi's institute and has since dedicated her life towards the propagation of Indian classical and folk dances, through the medium of print industry. On the other hand, one can witness the equally creditable contributions of Sumitra towards the 
emancipation of national cultural heritage through Kathak Kendra, especially in hosting conferences on performing arts regularly, to harmonize disparate views amongst artists across the nation.

The proposal to assemble artists for conferences or festivals was first proposed by the great singer and composer, Ravi Shankar in the year 1947. As the independence of India was dawning, musicians from all across the nation organised a performance at Lala Shri Ram's house. Famous amongst the budding artists as 'Bhaiji' (Khokar 20014, 43), Shri Ram provided financial and moral support to the restoration of art and culture in Delhi. After the success of the musical night, entrepreneurs like Shri Ram, Sumitra Charat Ram, Nawab of Pataudi, Nirmala Joshi, Sheila Bharat Ram and Kamala Narinderlal institutionalised the conferences and performances under the roof of Jhankar Music Circle, in 1947. The events of the music school were held at the Constitution Club in Delhi, sheltering approximately 250 people in the audience, but also opening up the performance to a larger crowd in the lawns. "People would bring their own baskets of snacks and have a picnic of sorts while listening to music.' (Khokar 2004, 44) Since the cultural milieu of the time was looked down upon there was an urgent need to familiarize the masses with a different perspective on music. The extensive gardens which hosted an audience for musical shows also provided space for exercising communal unity. The performances were addressed to the general public, and unlike courtly bethaks, these concerts were not reserved along class and gender divisions. The primary aim at democratising music on a large public platform, artists/entrepreneurs was not only to disseminate the art form but also to demonstrate their skills sanitized from its courtly associations. This was a significant development in cultural nationalisation and propogation of performing arts. These cultural festivals were initiated with the model for free interaction between different classes of the society and learning through sharing became its characteristic.

Though the programme began with a democratic perspective it largely remained an elite affair. Unlike private performances of the court these events were legitimate art expositions by the cultural scholars. Cultural performances intercepted with paper presentations and associated demonstrations limited its audience to art scholars. Thus the ideal democratic space for cultural interaction once again circumscribed the interests of the elite audience who were either artists or art scholars. Though the house was opened to questions and comments on the paper presentations in order to encourage audience participation it once again eliminated the general public from the discourses tabled. On the other hand, these conferences provided the platform for scholars to demonstrate their intellectual skills in performing arts who were not compelled to belong to any gharana or expected to practice the art form. The print media played an imporatant role in documenting the rising scholarly interest in the art form, and institutes like Lalit Kala Academy (estbd. 1954) became pillars to the sustenance and propagation of national culture.

The increasing numbers of scholars in the tradition of music encouraged Sumitra Charat Ram to accomplish the same in the field of dance. Nirmala Joshi suggested Sumitraji to engage artists in a pedagogical programme which will emancipate the status of performing arts as a discourse that can be studied. Hence the foundation of the Bhartiya Kala Kendra as an institution for the development of pedagogy and performance of Kathak was laid in 1952. In the following year, it attained a national status when it was brought under the government body of Sangeet National Academy of Dance and Music. Though Bhartiya Kala Kendra had acquired the status of a government institution, the classes were still held in a single room in Sumitra Charat Ram's house and with great persuasion, Shambhu Maharaj was employed to teach his first non-heritage student, Maya Rao. 
Under the government programme of annual scholarship, Maya Rao received the chance to enrol in a two-year course of Kathak at Bhartiya Kala Kendra. However, her keen interest in studying the art of 'abhinaya' (expression) in dance allowed her to extend the relationship with Maharajji for another year. During this time, Maya Rao also helped to organise the syllabus for the institution as well as group different aspects of Kathak into 'families'. A systematic approach towards dance was initiated by her that led to the abstract nature of improvisation to gradually recede to the background. As mentioned earlier, there was a compelling need to codify dance movements in an authorized manner to prevent disparity among prospective artists. Once again thus, Maya Rao subscribed towards standardization of Kathak by making exact sketches of mudras (gestures) told by Shambhu Maharaj for the following batches of students to follow. She named these drawings as 'skit-o-sketches' and sought 'to preserve his (Shambhu Maharaj) approach to dance. I even took his signature on the sketches in case unscrupulous people later palmed off their own work as his.' (Khokar 2004, 32-36).

A new phase in Kathak was thus reached with the support of print media and Maya Rao's efforts at homogenizing dance. Though the Kendra began its project with Nehru's vision of 'unity in diversity' by providing a platform for various artists to collaborate through the medium of art, the dominance of the Lucknow gharana became apparent with time. Increasingly, differences between Maya Rao and Sumitra Charat Ram also emerged and the influence of Shambhu Maharaj was replaced by his nephew Birju Maharaj. Substitution of Shambhu Maharaj with Birju Maharaj also meant that Maya Rao was not allowed by Sumitra Charat Ram to continue with the Kendra. After her return to the Kendra from a performance in Moscow, Rao discovered that 'politics had taken over, with Birju Maharaj saying that if I returned to the Kendra he would not continue.' (Khokar 2004, 59) The syntax of Kathak once again underwent a change and a similar pattern of codification and standardization was published at the time of Birju Maharaj's reign in Kathak Kendra (Chakravorty 2008, 69). However, the supremacy of a singular gharana style prevailed which also meant complete marginalisation of other gharnas and also centralisation of Kathak at Bhartiya Kala Kendra.

The effective use of print media for the propagation of Kathak heralded a new age of cultural nationalism. Though the books published on the art of Kathak was accessed by only a limited group of dancers and Kathak gurus, their dissemination through performances created a singular view-here it is important to remember that it was the Lucknow school of Kathak which was becoming popular amongst the masses. Taking the cue from Benedict Anderson's discussion on the close link between national consciousness and print culture, we can trace a similar pattern of development in Kathak. These books on Kathak were largely responsible in producing a communitarian feeling among different artists and thus homogenising their views with the prefix 'classical', or traditional Kathak. 'Classical' thus became the root term to define authenticity in Kathak and anything outside the 'tradition' was received with scepticism. At one of the National Dance Festivals held at Bhartiya Kala Kendra, Balasaraswathy, a Bharatnatyam dancer, assured her faith in the 'unique beauty' of Kathak as displayed by Achchan Maharaj, contrary to the 'hideous distortions and misinterpretations' in Madras (qtd. in Khokar 2004, 58). Balasaraswathy's review on Achchan (and Shambhu) Maharaja reiterated not only the autonomy of their art form, but also compelled the art educators and Kathak scholars to re-imagine the sense of community and tradition. 


\section{Conclusion}

In this light, we can also look at the development in broadcasting services in the mid-twentieth century through examples of sound and visual media. 'All India Radio', established in 1930, and 'Doordarshan', in 1959, were the two main national channels through which the Government intended to advaance Nehru's vision of 'unity in diversity'. Though secularism was the launching pad for both channels, Hindi became the only means of communication. At the same time, debates about 'pure' Hindi prevailed in the background; while 'a regional language invented by a self-seeking upper caste local elite desperate to exercise national dominance' (Bhattacharya qtd. in Rai 2002, xi) was occupying the space of public services of broadcasting. I do not intend to explore the debates regarding convergence of different dialects in the construction of Hindi around this time. Instead what I would like to briefly look at is the manner in which cultural programmes were outsourcing Hindi as a national language.

Pallabi Chakravorty in 'Public Modernity and Classical Kathak' traces the contribution of State television in advancing cultural knowledge among the masses in post-independence India. The essay gives a useful insight into the rise of 'high culture' as a by-product of the pan-Indian cultural programme initiated by the launch of Doordarshan. Early videos on classical Indian dance and music assist this argument; introduction to the performance is preceded in elitist Hindi which was restricted to a particular class of audience, while alienating others. Kathak was now a part of the 'high culture' and freed itself from the strangles of its history. At secondary level, detailed introduction of the artist and his/her performance encouraged the audience to assume the position of passive performers and active critics of Kathak. Gradually through popular media, the audience could claim knowledge of the national classical dance as well as develop a sense of nationhood and community.

As a larger group of people participated as cultural critics, especially in the domestic space, Kathak's Mughal past was revisited with a new perspective. Popular cinema in the 1950s India undertook the cleansing project of Kathak from its nautch associations. Devdas, Mughal-eAzam and Pakeezah became period films in the Indian cinema which reminisced about the courtesan culture of the North. In each of these movies the courtesan was highlighted as a sympathetic figure in love with the male protagonist. The love shared between them legitimised the presence of the nautch dancer in a public space of the court and the domestic space of the film audience. A combination of glamour and traditional Kathak performances on the national television henceforth paved way for middle class women to enter the space of public performance. Though the patronage of male Kathak dancers continued to overpower the space of institutional pedagogy, women performers and gurus were gradually moving towards the centre. The project of legitimising female Kathak dancers on the stage initiated by Madame Menaka was furthered by Kumudini Lakhia especially in her thematic performances on women emancipation. Though the scope of this paper does not allow me to study the development of Kathak in its later stages, yet it is an interesting study of how Kathak from Leila Sokhey's adoption of the stage name as Madame Menaka led to Kumudini Lakhia's semi-autobiographical choreographies in the period following Indian Nationalim. 


\section{Notes}

i One of the many ways in which this change was visible was in the use of lehra in music, that is, a repetitive and monotonous style suited for the courts was discarded and 'orchestral music in different talas were set in lilting Raga-Raginis' (Misra 1992, 20) which became popular with the masses.

ii The presence of the female Kathak dancer was legitimised by orienting the dance form as mentioned in the Natyashastra, i.e., by textually following the rules of performance, as well as by associating the dancer with apsara (muse) performing for the God and men.

iii One can look at early photographs and a short archival German film Der Tiger Von Eschnapur, (trans. as Deva Vijaya Nritya) to draw comparisons between Shankar and Menaka's dance style.

${ }^{\text {iv }}$ An interesting account of it is Birju Maharaj's interview on the origins of Kathak wherein he recounts the dream of his great grandfather's dream of Krishna instructing him on the art of Kathak. Rise of the Lucknow gharana was historically well placed in the accounts of the Mughal courts on dance and music; religious inclinations were constructed to give authenticity to the ancestral art and its patrons.

${ }^{v}$ Kothari's book on Kathak also gives a brief account of the rise of other possible gharanas and the political reasons for their failure.

\section{Bibliography}

Ahmad, Aijaz. "Literary Theory and 'Third World Literature': Some Contexts." In In Theory: Classes, Nations, Literatures, 43-72. London: Verso, 2000, 1992.

Andeerson, Benedict. Imagined Communities: Reflections on the Origin and Spread of Nationalism. London: Verso, 2006, 1983.

Appadurai, Arjun. "How Histories Make Geographies: Circulation and Context in a Global Perspective." In The Future as Cultural Fact: Essays on the Global Condition, 61-69. London: Verso, 2013.

Appadurai, Arjun. Modernity at Large: Cultural Dimensions of Globalization. Minneapolis: University of Minnesota Press, 2005, 1969.

Azad, Maulana. "Indian Council for Cultural Relations." http://www.iccrindia.net/azad/speech.pdf

Banerjee, Projesh. Uday Shankar and His Art. Delhi: B.R. Publishing Corporation, 1982.

Benjamin, Walter. The Work of Art in the Age of its Technological Reproducibility, and Other Writings on Media. Edited by Brigid Doherty, and Thomas Y. Levin Michael W. Jennings. Translated by Rodney Livingstone, Howard Eiland, and Edmund Jephcott. London: Harvard University Press, 2008.

Banerjee, Projesh. Uday Shankar and His Art. Delhi: B.R. Publishing Corporation, 1982.

Bhakle, Janaki. Two Men and Music: Nationalism in the Making of an Indian Classical Tradition. New York: Oxford University Press, 2005.

Bhattacharya, Neeladari. Editorial Preface to Hindi Nationalism, by Alok Rai, (vii- xii). Delhi: Orient Longman Private Limited, 2002, 2001.

Chakravorty, Pallabi. Bells of Change: Kathak Dance, Women, and Modernity in India. Calcutta: Seagull Books, 2008.

Chakravorty Pallabi. Dance Matters: Performing India. Edited by Pallabi Chakravorty and Nilanjana Gupta. New Delhi: Routledge, 2010.

Chatterjee, Partha. "The Nation and its Women." In The Nation and its Fragments: Colonial and Postcolonial Histories, 116-134. New Jersey: Princeton University Press, 1993. 
Desai, Niranjan. "The Festival of India in Britain, 1982." The Round Table: The Commonwealth Journal of International Affairs 72.286 (1983): 286-291.

Devdas. Directed by Sanjay Leela Bhansali. India: Red Chillies Entertainment, 2002. DVD, 185 min.

Dhar, Kumkum, interview by Suman Bhagchandani. (March 2015).

Ghosh, Sushmita, interview by Suman Bhagchandani. (Febraury-June 2015).

Guha, Ramachandra. India After Gandhi: The History of the World's Largest Democracy. London: Macmillian, 2008, 2007.

Jharta, Mohan Jharta and Bhavna. "Globalization and Higher Education in India: Issues and Concerns." In Socio-Cultural Diversities and Globalization: Issues and Perspectives, by S.R. Mehta, 283-302. Shimla: Indian Institute of Advanced Studies, 2010.

Joshi, Damyanti. Madame Menaka. Delhi: Sangeet Natak Akademy, 1982.

Jung, Anees. "Tarnished Gilt and Twinkling Feet." The Times of India, 1969.

Khokar, Ashish. Guru Maya Rao. Banglore: EKAH-Bios, 2004.

Khokar, Ashish. Shriram Bhartiya Kala Kendra: A History-Sumtra Charat Ram. New Delhi: India Roli Books, 2004.

Khokar, Mohan. "The Day of the Nautch and the Nautchwali." Sruti 145 (1996): 19-24.

Kothari, D.S. Report of the Education Commission, 1964-66. Ministry of Education, New Delhi: National Council of Educational Research and Training, 1970, 1966.

Kothari, Sunil. Kathak, Classical Indian Dance. New Delhi: Abhinav Publications, 1989.

Mehta, S.R. "Introduction." In Socio-Cultural Diversities and Globalization: Issues and Perspectives, by S.R. Mehta, 11-64. Shimla: Indian Institue of Advanced Study, 2010.

Menon, Ritu, ed. Women who Dared. New Delhi: National Book Trust, 2014.

Misra, Susheela. Some Dancers of India. New Delhi: Harman Publishing House, 1992.

Mughal-e-Azam. Directed by K. Asif. India: Shapoorji Pallonji, 196o. DVD, 197 min.

Maharaj, M.S. Kaliyanpukar and Birju. M.S. Kaliyanpukar's paper and Demonstration by Birju Maharaj. Cond. Dance Seminar. 1958.

Nagla, B.K. "Globalization and its Impact on Culture with Special Reference to India." In Socio-Cultural Diversities and Globalization: Issues and Perspectives, by S.R. Mehta, 235-258. Shimla: Indian Institute of Advanced Studies, 2010.

Neuman, Daniel M. The Life of Music in North India: The Organization of an Artistic Tradition. London: The University of Chicago Press, 1990, 1980.

Oldenburg, Veena Talwar. "The City Must be Clean: Control of Intemperance and "Other Social Diseases" ." In The Making of Colonial Lucknow, 1856-1877, 124-144. Surrey: Princeton University Press, 1984.

Oldenburg, Veena Talwar. "Lifestyle as Resistance: The Case of the Courtesans of Lucknow." 1990. http://www.columbia.edu/itc/mealac/pritchett/oourdu/umraojan/txt_veena_o ldenburg.html.

Pakeezah. Directed by Kamal Amrohi. India: Kamal Amrohi, 1972. DVD, 147 min.

Sarkar-Munsi, Urmimala. "Traversing Traditions: Women in the Public Sphere." Zakir Hussain Delhi College. Delhi: University of Delhi, 2015.

Shah, Reena. Movement in Stills: The Dance and Life of Kumudini Lakhia. Ahmedabad: MapinLit, 2005. 
55 | Institutions of Change: Kathak dance from Courts to Classrooms

Singh, Veena, interview by Suman Bhagchandani. (March 2015).

Skaria, Alon Confino and Ajay. "The Local Life of Nationhood." National Identities 4.1 (2002): 7-24.

Thakurta, Tapati-Guha. “Wresting the Nation's Prerogative: Art History and Nationalism in Bengal.” In Monuments, Objects, Histories, 140-171. New York: Columbia University Press, 2004, 1983.

Umrao Jaan. Directed by Muzaffar Ali. India: Muzaffar Ali, 1981. DVD, 145 min.

Vatsyayan, Kapila. Dance in Indian Painting. Google Books. New Delhi: Abhinav Publications, 1982.

Vyas, D.G. Discussion on D.G. Vyas's paper on Kathak. Cond. Dance Seminar. 1958. Audio.

Walker, Mararet E. India's Kathak dance in Historical Perspective . Canada: Ashgate Publishing Limited , 2014 .

Suman Bhagchandani is an M.Phil (English) scholar of University of Delhi. Her dissertation titled Nostalgic Innovations: Pedagogy and Peformance in Kathak is a study in the changing patterns of Kathak in institutions and on stage. She has also studied Kathak in contexts of Bollywood culture, Religious and Gender dichotomies and has published a paper on Kathak as well as presented few on the same. As an aspiring Ph.D. scholar, she aims to study Kathak in the context of body and performance literature. 